\title{
PENGGUNAAN AUGMENTED REALITY UNTUK MEMFASILITASI PERUBAHAN REPRESENTASI KONSEPTUAL SISWA TENTANG SISTEM PERNAPASAN
}

\author{
Annisa Syafigha Putri ${ }^{1}$, Ari Widodo ${ }^{2}$, Diana Rochintaniawati ${ }^{3}$ \\ 1,2,3 Program Studi Pendidikan Biologi FPMIPA Universitas Pendidikan Indonesia \\ *Korespondensi Author: syafighaannisa@gmail.com
}

\section{INFOARTIKEL}

\section{Riwayat artikel:}

Diterima 26 Agustus 2020

Revisi 28 November 2020

Dipublikasikan 28 Desember 2020

Kata kunci:

Augmented Reality, Materi Sistem Pernapasan, Perubahan Representasi Konseptual

\section{ABSTRAK}

Augmented Reality (AR) merupakan teknologi tepat guna dalam pendidikan yang dapat memvisualisasikan objek maya menjadi seolah nyata. AR dapat mempermudah pemahaman siswa dalam memahami konsep yang abstrak. Materi sistem permapasan yang cukup abstrak perlu dibantu menggunakan $A R$ karena penggunaan AR dapat memvisualisasikan objek yang bersifat mikroskopik dan submikroskopik. Visualisasi yang ditampilkan AR mampu membuat siswa melihat seolah secara nyata organ sistem pernapasan lengkap dengan proses yang terjadi. Tujuan dari penelitian ini adalah mengidentifikasi penggunaan $A R$ dalam memfasilitasi perubahan representasi konseptual siswa tentang sistem pernapasan. Penelitian ini menggunakan metode Quasi Experimental dengan desain Non-Equivalent Control Group Design. Dalam pelaksanaannya pembelajaran pada kelas eksperimen menggunakan AR dengan memindai marker yang terdapat pada LKS sedangkan pada kelas kontrol melaksanakan pembelajaran menggunakan power point. Perubahan representasi konseptual siswa dianalisis berdasarkan pada penggunaan bentuk dan level representasi serta akurasi dan kedalaman konsep. Hasil penelitian menunjukkan AR dapat memfasilitasi perubahan bentuk dan level representasi. Kelas eksperimen menunjukkan akurasi dan kedalaman konsep yang lebih baik dibandingkan kelas kontrol. Jawaban di kelas eksperimen sudah menunjukan pada proses yang merinci lengkap dengan proses difusi, sedangkan pada kelas kontrol tidak. Perubahan bentuk representasi didominasi oleh bentuk tulisan kemudian berubah menjadi tulisan \& gambar. Sebelum menggunakan AR level representasi didominasi oleh level makroskopik. Sedangkan Setelah menggunakan AR level representasi siswa didominasi oleh level representasi mikroskopik.

\section{ABSTRACT}

Augmented Reality (AR) is an appropriate technology in education that can visualize object into reality. AR can facilitate students' understanding to the abstract concepts. The purpose of this study was to identify the use of $A R$ in facilitating students' representation conceptual change about respiratory system. This study used the Quasi Experimental Design method with the design Non-Equivalent Control Group Design. The implementation learning in the experimental class use AR by scanning the markers provided in worksheet, while in control class using power point. The data was collected using essay item test given before and after learning to measure change of the conceptual representation. The analysis of students' representation conceptual change is based on the type and level of representation as well as the accuracy and depth of concept. The result of the study showed that AR can facilitate type and level of representation change. The experimental class showed better accuracy and depth of concept comparing the control class. Type of representation change which was dominated by text change into text \& pictures. Level of representation change which was dominated by macroscopic level change into microscopic level. 
How to Cite:

Putri, A.S., Widodo, A., \& Rochintaniawati, D. (2020). Penggunaan Augmented Reality Untuk Memfasilitasi Perubahan Representasi Konseptual Siswa Tentang Sistem Pernapasan. Jurnal Pelita Pendidikan, 8(4), 195-205.

\section{PENDAHULUAN}

Biologi merupakan cabang ilmu yang mempelajari tentang makhluk hidup beserta kehidupannya (Sanjaya \& Rustaman, 2018). Konsep pada pelajaran biologi sering dijumpai dalam kehidupan sehari-hari. Walaupun sering dijumpai dalam kehidupan sehari-hari konsep biologi tidak semuanya bersifat konkret, akan tetapi banyak konsep yang bersifat abstrak (Masruroh, Karyanto

\& Indrowati 2014). Konsep yang bersifat konkretmudah dipahami oleh siswa karena sebagian besar merupakan sesuatu yang dapat dilihat secara nyata dengan indera. Sedangkan pada materi yang bersifat abstrak siswa sering merasa kesulitan dalam memahami suatu konsep karena tidak terlihat secara nyata dan berkaitan dengan suatu proses sehingga sulit untuk siswa bayangkan bagaimana proses yang sebenarnya terjadi (Sari,2018).

Sistem pernapasan terdiri dari konsep yang bersifat konkret dan abstrak. Konsep yang bersifat abstrak dalam materi sistem pernapasan sering kali dianggap sulit oleh siswa karena banyak konsep yang membahas mengenai jalannya proses yang kompleks dan tidak mudah untuk siswa bayangkan bagiamana proses yang sebenarnya terjadi atau bersifat mikroskopik. Diperlukan kemampuan representasi yang baik pada siswa agar konsep yang dianggap sulit dapat dengan mudah dipahami oleh siswa serta dapat membantu siswa dalam memahami konsepkonsep yang sulit dilihat secara kasat mata seperti pada konsep proses bernapas dan proses pertukaran gas (Fadhilah, 2018).

Siswa dapat memahami konsep dan proses bernapas pada manusia jika sudah mampu merepresentasikan jalannya proses bernapas serta proses pertukaran gas dengan tepat dan dapat menyebutkan bagian mikroskopik maupun submikroskopik dari proses tersebut. Representasi merupakan kemampuan seseorang untuk menjelaskan kembali suatu fenomena secara bermakna atau sesuatu yang dapat disimbolkan atau digambarkan atau direkontruksi kembali mengenai suatu objek atau proses (Waldrip et al, 2010). Representasi memiliki peran dalam memfasilitasi pemahaman siswa pada objek atau konsep yang abstrak (De Jong \& Van Joolingen, 1985). Maka dari itu, untuk mempelajari konsep yang bersifat abstrak serta mikroskopik maupun submikroskopik dibutuhkan kemampuan representasi dengan berbagai format agar siswa dapat lebih mudah dalam memahami konsep yang abstrak (Chaifa, Diantoro \& Mahanal, 2017). Representasi konseptual siswa dapat mengalami perubahan baik secara bentuk maupun level. Transformasi dari suatu bentuk representasi ke bentuk representasi lainnya memungkinkan siswa untuk membuat pemahaman mereka lebih bermakna (Hand, Gunel \& Ulu, 2009). Selain itu, menurut Anam (2019) bahwa konsepsi pada dua level representasi makroskopik dan sub mikroskopik secara verbal dan visual dapat membantu perubahan konsepsi siswa menjadi lebih baik. Akan tetapi kemampuan representasi siswa pada bidang biologi masih berada pada kategori rendah (Chaifa et al, 2017).

Tingkat representasi dalam biologi terdiri atas empat tingkatan representasi yang perlu dipertimbangkan untuk pemahaman secara utuh dari fenomena biologis yaitu: 1) tingkat makroskopik, yaitu menunjukan struktur biologis yang dapat dilihat secara kasat mata, 2) tingkat mikroskopik, yaitu struktur hanya dapat dilihat melalui mikroskop (tidak dapat dilihat secara kasat mata), 3) tingkat submikroskopik yaitu melibatkan DNA, protein dan berbagai konsep biokimia, 4) tingkat simbolik, yaitu mekanisme penjelasan dari fenomena yang diwakili oleh simbol-simbol, rumus, persamaan kimia, jalur metabolisme, genotip, warisan pola, pohon (Treagust \& Tsui, 2013).

Kemampuan representasi siswa dapat ditingkatkan dengan implementasi teknologi dalam media pembelajaran. Seiring berkembanganya teknologi di zaman modern terutama dalam bidang pendidikan, teknologi Augmented Reality (AR) hadir dengan beberapa kelebihan yaitu menunjukkan visualisasi yang menarik, interaktif, efektif dalam penggunaannya sehingga berpotensi kuat untuk meningkatkan proses pembelajaran (Sungkur \& Panchoo, 2016). Selain itu menurut Nurhasanah, Widodo \& Riandi (2019), aplikasi AR merupakan teknologi yang cukup efektif dalam memberikan kemudahan terutama dalam mempelajari materi biologi yang bersifat abstrak atau sulit dibayangkan seperti pada sebuah proses atau mekanisme.

Berdasarkan keunggulan tersebut, untuk mengatasi masalah yang sebelumnya diuraikan, $A R$ dapat digunakan untuk membantu siswa dalam 
mengembangkan kemampuan representasi. Sejalan dengan hasil penelitan Nielsen et al (2016), melalui penggunaan AR guru dapat membimbing siswa untuk dapat menghasilkan kemampuan representasi mereka sendiri. Teknologi AR dapat memvisualisasikan konsep yang abstrak atau fenomena yang tidak dapat diamati secara kasat mata. Hal tersebut dapat menjadikan pemahaman siswa mengenai suatu materi meningkat karena siswa dapat membayangkan bagaimana proses yang sebenarnya terjadi. Penggunaan representasi mampu membantu siswa dalam mempelajari konsep biologi. Suatu proses yang terjadi didalam tubuh sulit untuk siswa bayangkan, jika dalam proses pembelajaran menggunakan kemampuan representasi, maka akan mampu membantu pemahaman dan kemampuan siswa dalam memecahkan masalah (Ainsworth, 2006).

\section{METODE PENELITIAN}

Metode yang digunakan pada penelitian ini adalah Quasi Experimental Design dengan desain penelitian yang digunakan yaitu Non-Equivalent Control Group Design. Pengambilan sampel dilakukan tidak secara acak dan dalam penelitian terdapat dua kelompok yaitu kelompok eksperimen yang diberikan perlakuan pembelajaran menggunakan Augmented Reality dan untuk kelompok kontrol dilakukan pembelajaran seperti biasa dengan menggunakan power point.

Populasi dalam penelitian ini yaitu siswa kelas XI MIPA di salah satu Sekolah Menengah Negeri Atas (SMA) Negeri Kota Bandung. Sampel yang diambil dalam penelitian ini yaitu siswa kelas XI MIPA 1 dan kelas XI MIPA 2. Penentuan sampel dilakukan secara purposive sampling karena dalam penelitian ini dibutuhkan kelas yang seluruh siswanya memiliki smartphone.

Instrumen penelitian terdiri dari soal uraian representasi konseptual. Soal uraian ini diberikan saat pretest dan posttest untuk mengatahui pengaruh perlakuan yang diberikan terhadap representasi konseptual siswa. Representasi konseptual dianalisis berdasarkan pengunaan bentuk dan level representasi serta akurasi dan kedalaman konsep.

Prosedur penelitian diawali dengan tahap persiapan dengan melakukan studi literatur, menyusun dan membuat instrumen penelitian. melakukan uji coba instrumen dan analisis instrumen yang akan digunakan serta membuat Augmented Reality untuk digunakan dalam penelitian. Prosedur dilanjutkan dengan tahap pelaksanaan yaitu proses pengambilan data. Kelas eksperimen melaksanakan pembelajaran menggunakan AR dengan cara memindai marker AR yang terdapat dalam LKS. Kelas kontrol melaksanakan pembelajaran tanpa menggunakan AR atau menggunakan power point. Sebelum dan setelah pembelajaran siswa diberikan soal pretest dan posttest. Tahap terakhir adalah melaksanakan pengolahan data, membuat pembahasan serta penarikan kesimpulan.

\section{HASIL DAN PEMBAHASAN}

Representasi siswa diawali dengan melihat bagaimana penggunaan bentuk representasi pada saat sebelum pembelajaran menggunakan AR maupun pembelajaran dengan non-AR. Pembelajaran materi sistem pernapasan ini difokuskan pada dua konsep utama yaitu konsep proses bernapas dan konsep pertukaran gas oksigen dan karbondioksida. Pada bagian ini lebih ditekankan pada perubahan kemampuan siswa dalam menggunakan bentuk representasi yang paling tepat dalam memahami konsep proses bernapas dan konsep proses pertukaran gas.

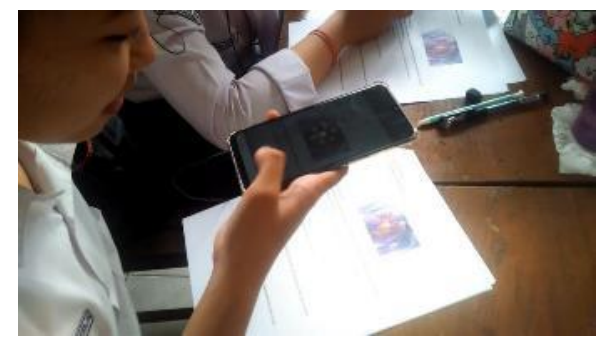

Gambar 1. Scanning Marker

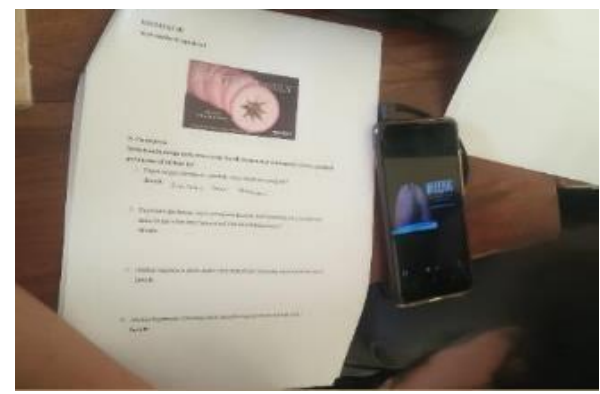

Gambar 2. Hasil Scanning Marker

Berdasarkan Gambar 3, perubahan bentuk representasi yang terjadi di kelas eksperimen lebih beragam dibandingkan pada kelas kontrol. Beragamnya perubahan bentuk representasi ini disebabkan karena penggunaan AR. Menurut Singhal et al (2012), penggunaan AR memungkinkan cara yang tepat untuk mewakili objek yang perlu divisualisasikan, menjadikan siswa dapat merepresentasikan suatu konsep ke dalam bentuk representasi lain. 
Selain itu menurut Kohl \& Noah (2006), siswa yang menggunakan berbagai bentuk representasi akan menunjukkan kemampuan pemahaman konsep yang lebih tinggi dibandingkan pada siswa yang hanya menggunakan representasi tunggal.

Perubahan bentuk representasi di kelas eksperimen didominasi oleh perubahan bentuk representasi tulisan menjadi bentuk tulisan dan gambar. Hal tersebut terjadi dikarenakan saat proses pembelajaran siswa dibantu dengan menggunakan AR yang dapat

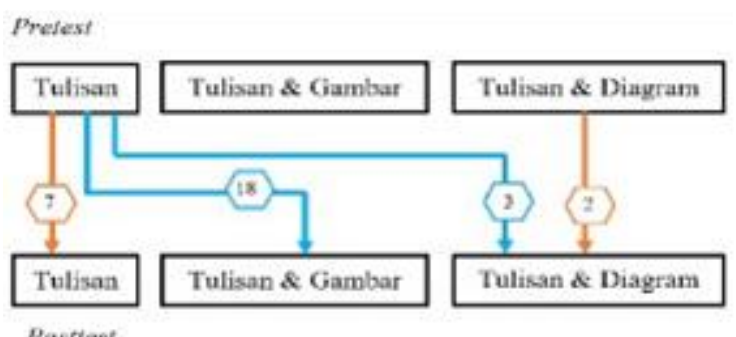

memvisualisasikan objek dengan baik, sehingga dapat mendukung siswa untuk mengeksplor informasi yang diperolehnya dan merepresentasikan pemahaman konsepnya ke dalam bentuk tulisan dan gambar. Contoh perubahan bentuk representasi tulisan menjadi bentuk tulisan dan gambar pada kelas eksperimen disajikan pada Gambar 4.

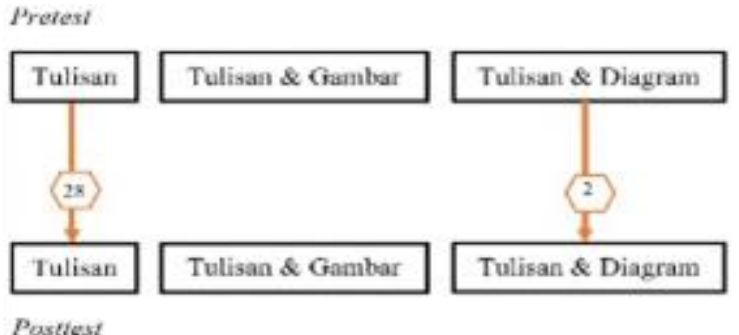

Gambar 3. Perubahan Bentuk Representasi pada Konsep Proses Bernapas (kiri: kelas eksperimen, kanan: kelas kontrol)

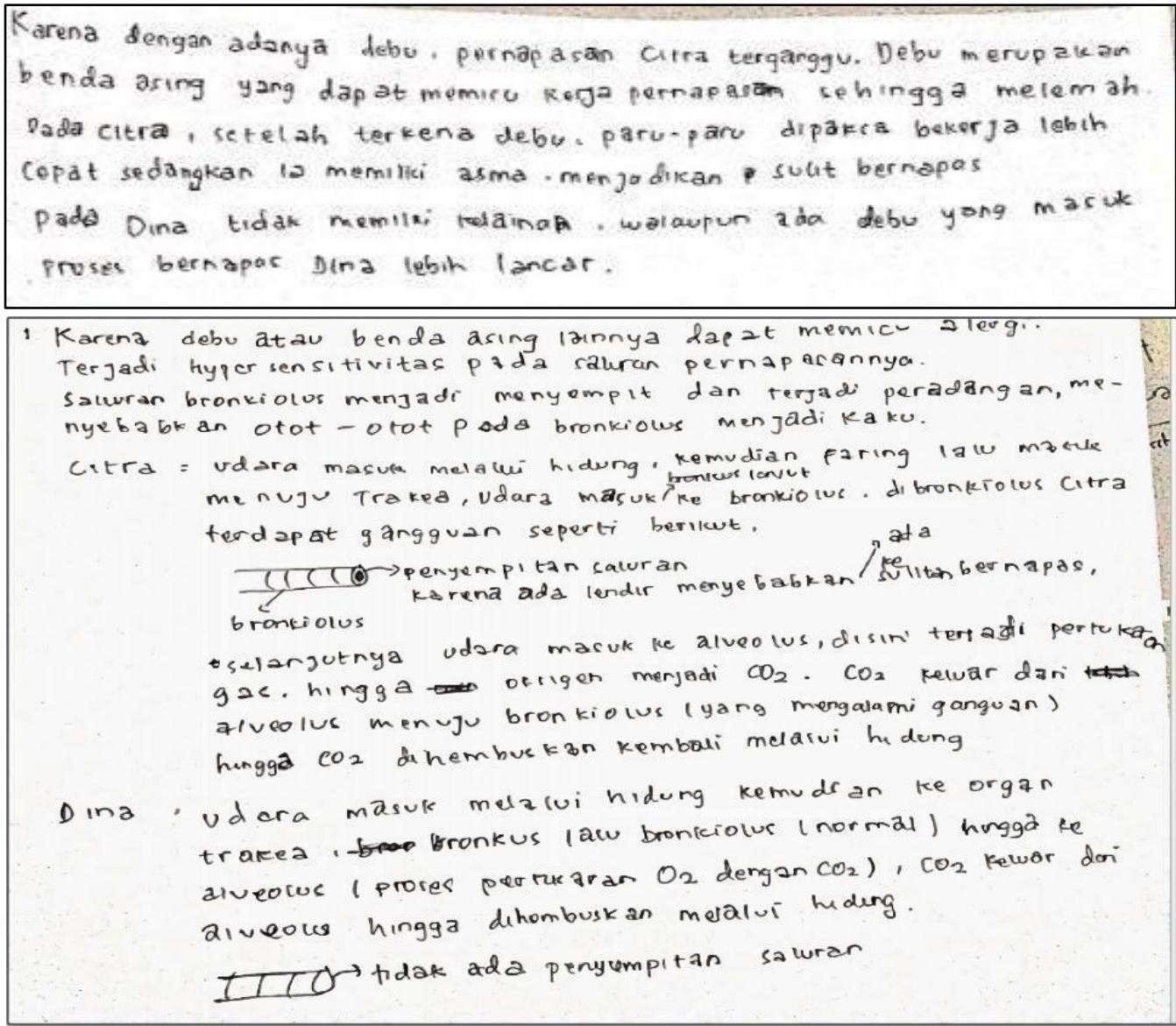

Gambar 4. Perubahan Bentuk Representasi Tulisan menjadi Bentuk Tulisan \& Gambar pada Konsep Proses Bernapas Kelas Eksperimen (atas: sebelum menggunakan $A R$, bawah: setelah menggunakan $A R$ ) 
Berdasarkan Gambar 4, sebelum pembelajaran dengan menggunakan $A R$, akurasi konsep menunjukkan jawaban yang disajikan kurang sesuai dengan konsep ilmiah. Kedalaman konsepnya pun masih kurang dijelaskan secara komprehensif dan sistematis. Jawaban siswa hanya sebatas menyebutkan proses bernapas secara umum dan singkat serta tidak disertai dengan menjelaskan organ-organ pernapasan yang terlibat. Setelah pembelajaran menggunakan $A R$, akurasi dan kedalaman konsep mengalami peningkatan yang baik. Jawaban yang disajikan sesuai dengan konsep ilmiah dan dengan kedalaman konsep sudah dijelaskan secara komprehensif dan sistematis. Siswa mampu menjelaskan proses bernapas dengan lengkap dan mampu menggambarkan perbedaan bronkiolus pada orang normal dan penderita asma.

Banyaknya siswa yang menggunakan bentuk representasi tulisan \& gambar setelah pembelajaran dengan AR dikarenakan, AR memiliki visualiasi objek yang baik sehingga siswa dapat memahami konsep bernapas dengan baik. Dalam proses pembelajaran dengan $A R$, siswa memiliki pengalaman belajar baru yang dirasakan secara individu untuk melihat proses bernapas yang sebenarnya terjadi. Sejalan dengan hasil penelitian penelitan Nielsen et al. (2016), penggunaan AR dapat memfasilitasi siswa dalam memvisualisasikan konsep sains yang abstrak sehingga menjadikan pemahaman mereka mengenai suatu konsep meningkat. Kemampuan representasi penting untuk siswa dikarenakan dengan menuangkan atau menjelaskan kembali dalam bentuk lain dapat membantu siswa memahami konsep yang bersifat abstrak sehingga menjadikan pemahaman konsep yang dipahami siswa lebih mendalam.

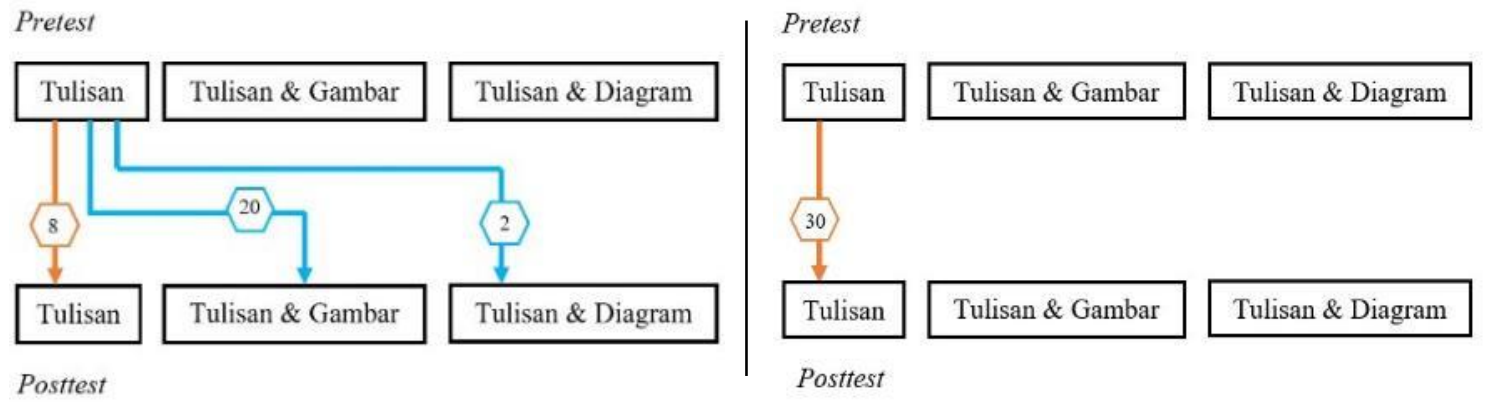

Gambar 5. Perubahan Bentuk Representasi pada Konsep Proses Pertukaran Gas (kanan: kelas eksperimen, kiri: kelas kontrol)

Gambar 5 menunjukkan perubahan bentuk representasi yang didominasi oleh perubahan bentuk tulisan menjadi tulisan \& gambar yang hanya terjadi pada kelas eksperimen. Perubahan bentuk representasi tulisan menjadi tulisan hanya terjadi pada 8 siswa dan untuk perubahan tulisan menjadi tulisan\&diagram terjadi hanya pada 2 siswa. Banyaknya siswa yang mengalami perubahan bentuk tulisan menjadi tulisan\&gambar disebabkan karena setelah pembelajaran menggunakan AR, siswa sudah dapat mengeksplor daya imajianasinya, kemudian merepresentasikan konsep proses pertukaran gas ke dalam bentuk representasi gabungan seperti tulisan dan gambar.

Berbeda halnya pada kelas kontrol, perubahan bentuk representasi didominasi oleh perubahan bentuk tulisan menjadi tulisan. Kurang beragamnya perubahan bentuk representasi pada kelas kontrol dikarenakan salah satu faktor yaitu dalam proses pembelajaran menggunakan power point. Siswa kurang dilatih oleh guru untuk menggali kemampuannya menggunakan bentuk representasi lain. Sejalan dengan hasil penelitian Nurmalasari (2016), guru tidak memberikan ruang yang luas kepada siswa untuk mengeksplor lebih dalam mengenai pemahaman konsepnya ke dalam bentuk representasi lain. Menurut Puspaningrum, Mahardika \& Supriadi (2015), kurangnya keterlibatan siswa dalam proses pembelajaran dikarenakan guru jarang menggunakan model pembelajaran yang disertai dengan metode demonstrasi ataupun eksperimen, sehingga siswa mengalami kesulitan dalam merepresentasikan konsep yang abstrak ke dalam bentuk representasi lain. 

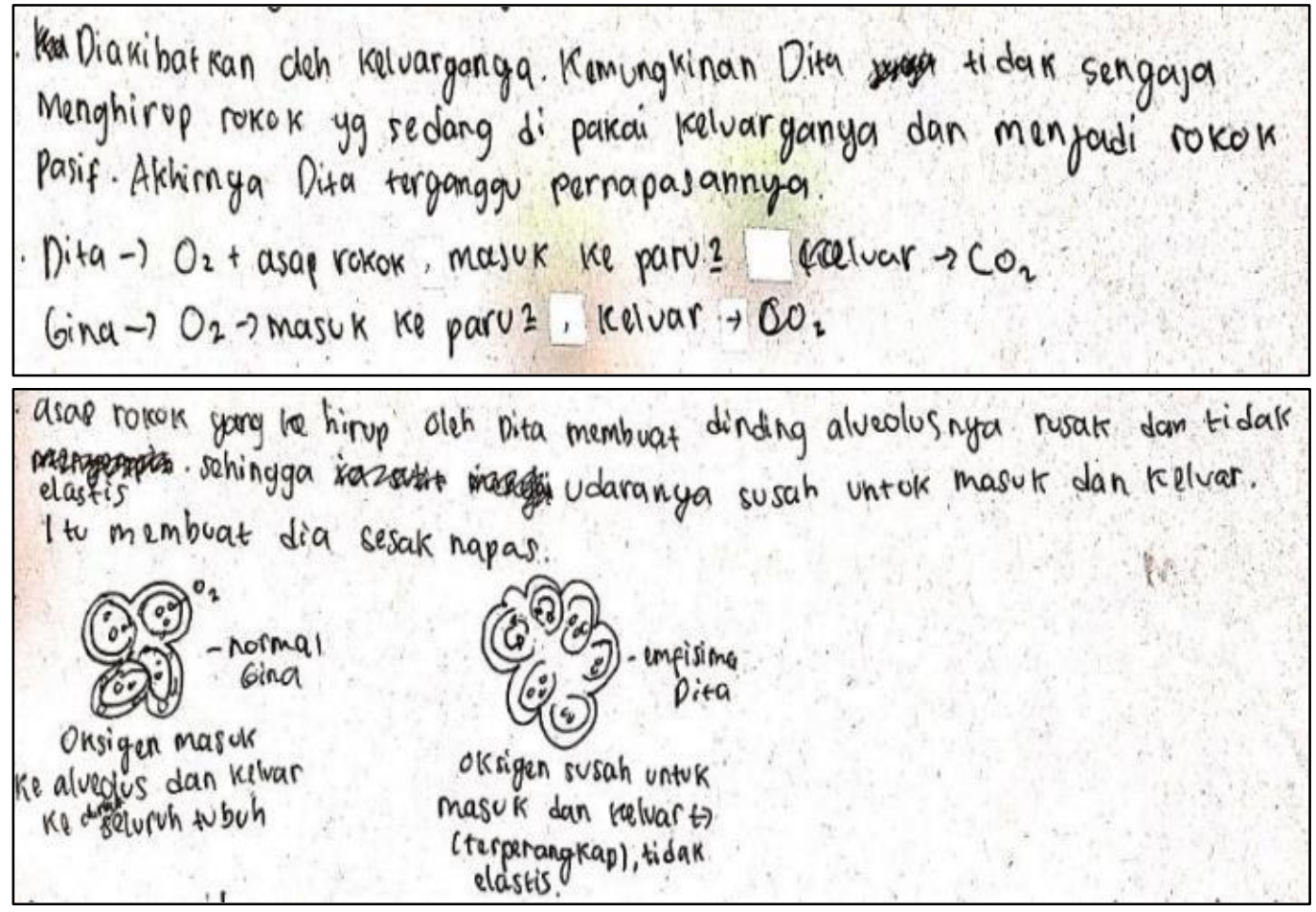

Gambar 6. contoh perubahan bentuk representasi tulisan menjadi tulisan \& gambar di kelas eksperimen (atas: sebelum menggunakan AR, bawah: setelah menggunakan AR)

Gambar 6 menunjukkan sebelum pembelajaran akurasi konsep yang kurang sesuai dengan konsep ilmiah, untuk kedalaman konsepnya jawaban yang disajikan siswa kurang dijelaskan secara komprehensif dan sistematis. Siswa belum dapat menjelaskan hingga proses difusi dan tempat terjadinya pertukaran gas. Setelah pembelajaran menggunakan AR, akurasi konsep sudah baik sesuai dengan konsep ilmiah dan untuk kedalaman konsepnya sudah dijelaskan lebih komprehensif dan sistematis. Jawaban yang disajikan siswa sudah dapat menjelaskan mengenai oksigen yang terperangkap dalam alveolus, menyebutkan perbedaan bentuk alveolus yang terdapat pada orang normal dan penderita emfisema. Namun masih terdapat sedikit kekurangan, siswa tidak menjelaskan hingga proses difusi.

Perubahan bentuk representasi tulisan menjadi tulisan dan gambar terjadi karena salah satu faktornya yaitu penggunaan AR dalam proses pembelajaran. Setelah pembelajaran dengan menggunakan $A R$, pemahaman siswa mengenai konsep proses bernapas berubah ke arah yang lebih baik. Sejalan dengan hasil penelitian Hand et al. (2009), bahwa transformasi dari suatu bentuk representasi ke bentuk representasi lainnya memungkinkan siswa untuk membuat pemahaman mereka lebih bermakna. Selain itu menurut Harley et al (2016), penggunaan AR dapat membuat siswa lebih memahami materi, karena materi yang disajikan dalam AR dijelaskan dan disampaikan seolah secara nyata. AR dapat memvisualisasikan konsep yang abstrak dengan baik sehingga pengetahuan dan pemahaman siswa meningkat.

\section{Perubahan Level Representasi}

Perubahan representasi konseptual siswa selanjutnya dianalisis dengan melihat bagaimana penggunaan level representasi dalam jawaban siswa, baik pada saat sebelum dan setelah pembelajaran menggunakan AR (kelas eksperimen) maupun non-AR (kelas kontrol). Level representasi yang digunakan oleh siswa secara umum dari keseluruhan konsep yaitu level makroskopik, mikroskopik dan submikroskopik.

Level representasi dapat digunakan untuk melihat sejauh mana pemahaman konsep biologi pada siswa. Pada bagian ini lebih ditekankan pada perubahan level representasi untuk mengetahui sejauh mana pemahaman siswa pada konsep proses bernapas dan konsep proses pertukaran gas. 
Pretest

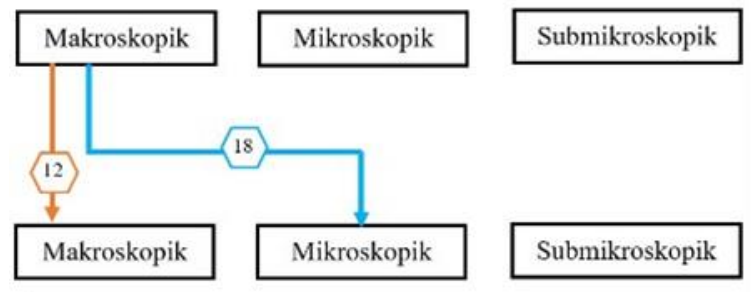

Gambar 7. Perubahan Level Representasi pada Konsep Proses Bernapas
Pretest

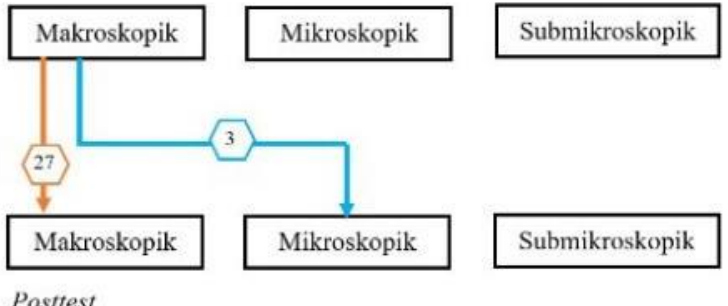

Gambar 7 menunjukkan perubahan level representasi di kelas eksperimen dan kelas kontrol. Perubahan tersebut meliputi perubahan level makroskopik menjadi makroskopik dan perubahan level makroskopik menjadi mikroskopik. Setiap siswa memiliki tingkat pemahamannya masingmasing dalam memahami konsep proses bernapas. Pada kelas eksperimen perubahan level representasi didominasi oleh perubahan level makroskopik menjadi mikroskopik, sedangkan di kelas kontrol didominasi oleh perubahan level representasi makroskopik menjadi level makroskopik.
Sebagian besar siswa saat pretest baik pada kelas eksperimen maupun kelas kontrol pemahaman mengenai konsep proses bernapas berada pada level makroskopik. Level makroskopik merupakan gerbang awal untuk memahami dan merepresentasikan suatu konsep kedalam level representasi selanjutnya (Anam, 2019). Berikut merupakan contoh perubahan level representasi makroskopik menjadi level mikroskopik di kelas eksperimen.
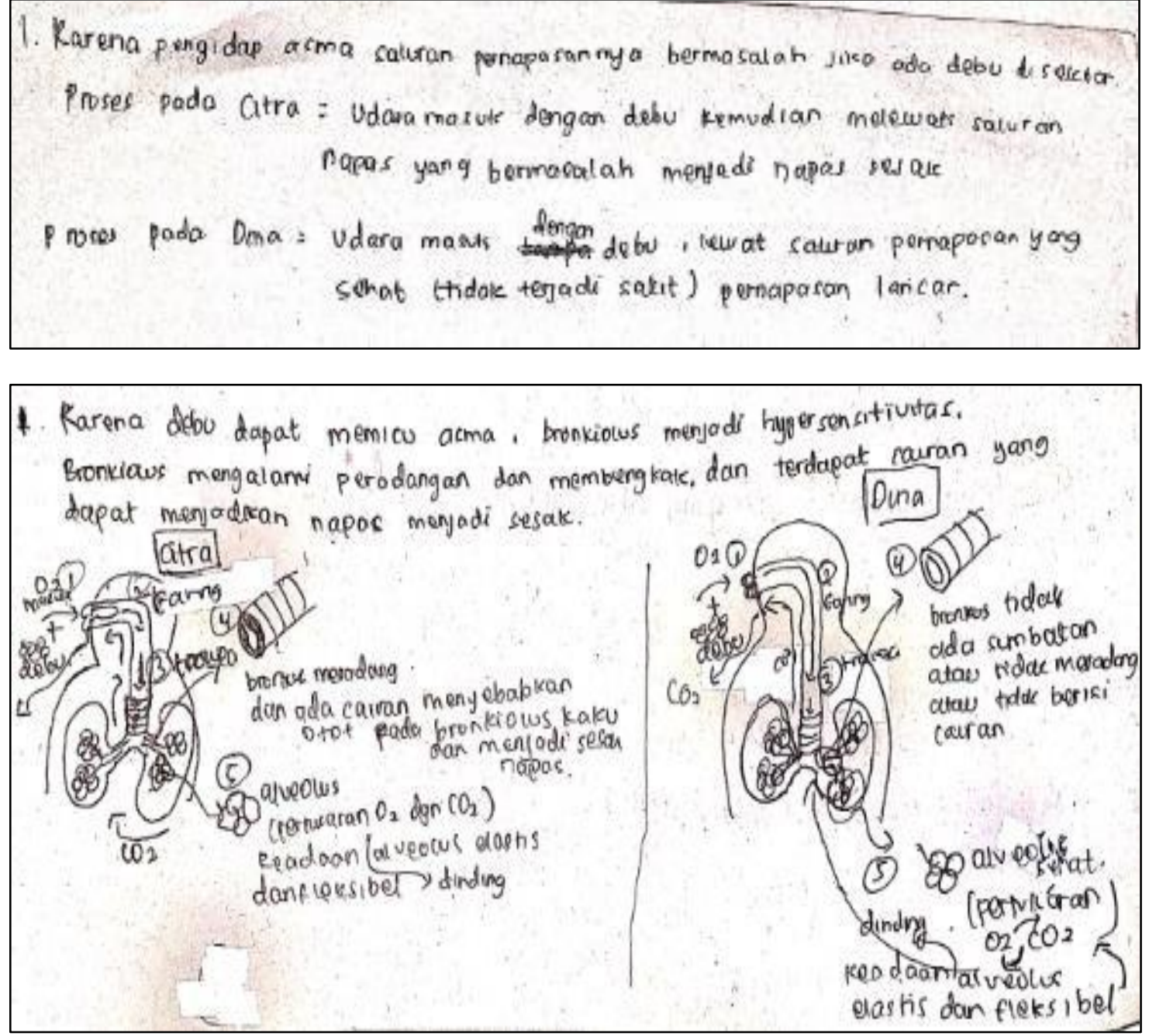

Gambar 8. Perubahan Level Representasi Makroskopik menjadi Level Mikroskopik pada Konsep Proses Bernapas Kelas Eksperimen 
Gambar 8 menunjukkan sebelum pembelajaran dengan AR akurasi konsep yang kurang sesuai dengan konsep ilmiah. Untuk kedalaman konsep, jawaban yang disajikan siswa masih kurang dijelaskan secara komprehensif dan sistematis. Level makroskopik ditunjukkan dengan menyebutkan saluran pernapasan bermasalah. Setelah pembelajaran menggunakan AR, menunjukkan akurasi konsep dan kedalaman konsep yang baik. Jawaban sudah sesuai dengan konsep ilmiah dan dijelaskan secara komprehensif dan sistematis. Level mikroskopik ditunjukkan siswa dengan menyebutkan otot bronkiolus pada penderita asma kaku serta menjelaskan konsep proses bernapas lebih mendalam.
Penggunaan AR dapat membantu siswa dalam memahami konsep proses bernapas lebih dalam. Pemahaman siswa mengalami peningkatan, yang dibuktikan dengan adanya perubahan level representasi makroskopik menjadi level mikroskopik dengan akurasi konsep dan kedalaman konsep yang mengalami perubahan menjadi lebih baik. Menurut Juannita \& Adhi (2017), penggunaan AR dalam proses pembelajaran biologi dapat meningkatkan pemahaman konsep biologi. Selain itu menurut Sungkur \& Panchoo (2016), AR telah terbukti dapat membantu dalam memahami konsepkonsep kompleks seperti pada konsep sistem pernapasan.

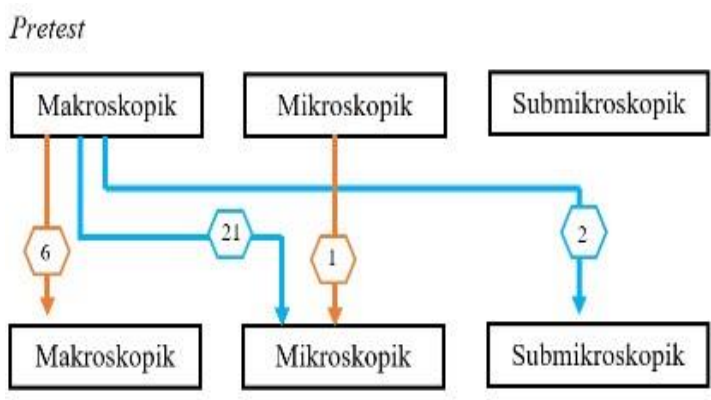

Posttest

\section{Pretest}

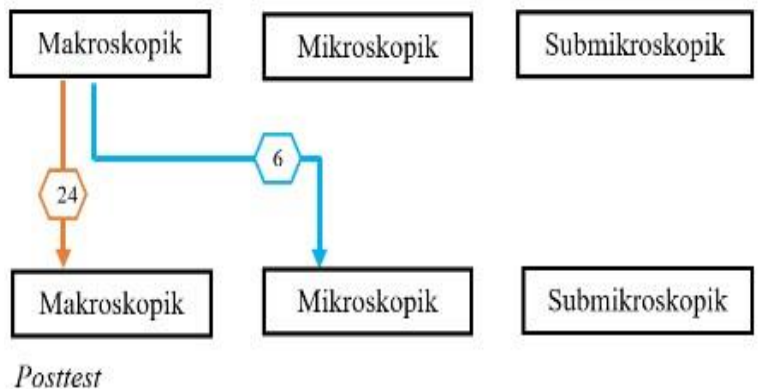

Gambar 9. Perubahan Level Representasi pada Konsep Proses Pertukaran Gas antara Kelas Eksperimen (kanan) dan Kelas Kontrol (kiri)

Perubahan level representasi yang terjadi di kelas eksperimen lebih beragam dibandingkan dengan kelas kontrol. Sebagian besar siswa saat pretest baik pada kelas eksperimen maupun kelas kontrol pemahaman mengenai konsep proses pertukaran gas berada pada level makroskopik. Berdasarkan hasil observasi saat pembelajaran, tingginya persentase level representasi makroskopik disebabkan karena siswa hanya mengandalkan kemampuan dan pemahaman awal yang dimiliki. Hal ini sejalan dengan Hanif, Sopandi \& Kusrijadi (2013), dalam penelitiannya menyebutkan bahwa level makroskopik paling banyak digunakan oleh siswa. Hal ini berarti pemahaman siswa saat sebelum mendapatkan konsep yang utuh sebatas pada level makroskopik. Semula siswa berada pada level representasi makroskopik, namun setelah pembelajaran dengan $A R$, pemahaman siswa berada pada level representasi lain. Gambar 10 merupakan contoh jawaban perubahan level representasi makroskopik menjadi level submikroskopik.

Berdasarkan Gambar 10, sebelum pembelajaran menunjukkan akurasi konsep yang kurang sesuai dengan konsep ilmiah. Kedalaman konsepnya yang disajikan kurang dijelaskan secara komprehensif dan sistematis. Level makroskopik ditunjukkan dengan menyebutkan asap rokok yang terhirup menyebabkan sesak napas. Setelah proses pembelajaran menggunakan $A R$, menunjukkan akurasi konsep yang sangat baik sesuai dengan konsep ilmiah. Untuk kedalaman konsepnya pun baik, siswa sudah menjelaskan secara komprehensif dan sistematis. Level submikroskopik ditunjukkan dengan menjelaskan keadaan perbedaan alveolus lengkap beserta dengan proses difusi yang terjadi.

Perubahan level makroskopik menjadi level submikroskopik hanya terjadi pada sebagian kecil siswa, hal ini disebabkan karena untuk mencapai pemahaman hingga level submikroskopik dibutuhkan pemahaman konsep yang jauh lebih bermakna. Sebagian besar siswa masih mengalami kesulitan jika harus mencapai pemahaman hingga level submikroskopik. Menurut Williamson \& Abraham (1995), level submikroskopik merupakan level yang paling sulit dipelajari karena kurangnya pemahaman siswa. Walaupun sudah menggunakan AR dengan visualisasi objek yang baik, akan tetapi kemampuan representasi setiap siswa berbeda. 
Belum sepenuhnya pemahamannya siswa berada pada level submikroskopik terutama pada konsep proses pertukaran gas. Sejalan dengan hasil penelitian Lestari et al (2018), setiap siswa memiliki kemampuan representasi yang beragam, kemampuan representasi ini harus terus dilatih untuk mengembangkan pemahaman konsep.

Augmented Reality sangat memfasilitasi perubahan representasi konseptual siswa pada konsep proses pertukaran gas dikarenakan, pemahaman siswa sudah mampu berada pada level submikroskopik serta apabila dilihat dari segi akurasi dan kedalaman konsep yang ditunjukkan setelah menggunakan AR menunjukkan hasil yang lebih baik, lebih lengkap dan lebih sistematis. Selain itu, AR yang digunakan dalam penelitian memvisualisasikan dengan jelas bagaimana proses pertukaran gas yang terjadi dalam alveolus dan jaringan-jaringan tubuh serta memvisuaslisasikan bagaimana oksigen dan karbondioksida berdifusi dalam kapiler.

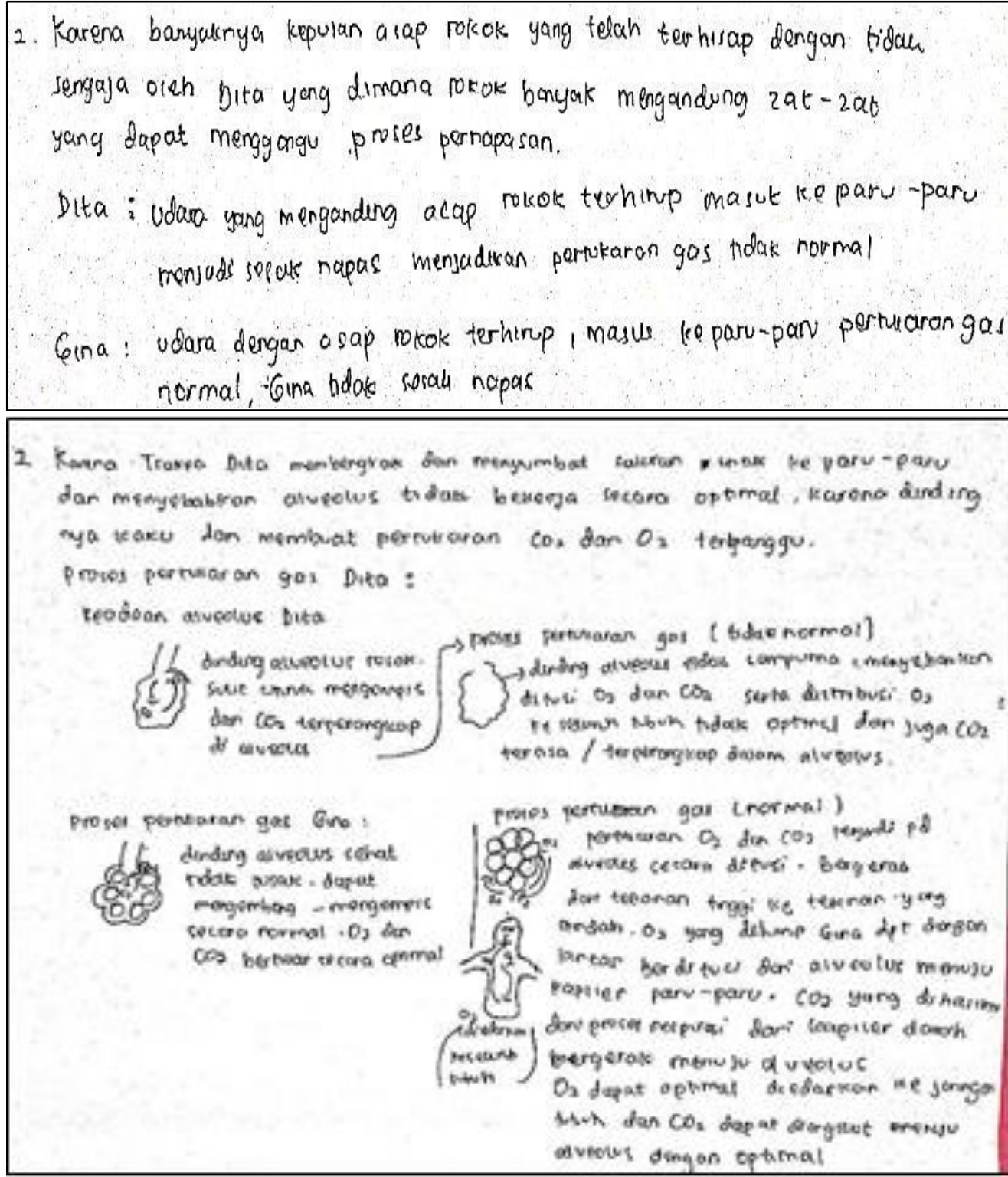

Gambar 10. Perubahan Level Representasi Makroskopik menjadi Level Submikroskopik pada Konsep Proses Pertukaran Gas Kelas Eksperimen 


\section{KESIMPULAN}

Penggunaan AR dalam proses pembelajaran dapat memfasilitasi perubahan bentuk dan level representasi konseptual siswa pada konsep proses bernapas dan proses pertukaran gas. Perubahanperubahan bentuk dan level representasi yang terjadi beragam dikarenakan AR memiliki visualisasi yang baik yang dapat membangun interpretasi siswa lebih luas dan utuh sehingga dapat membantu siswa dalam memahami konsep yang abstrak dan merepresentasikan pemahamannya ke dalam bentuk dan level representasi lain.

\section{DAFTAR PUSTAKA}

Ainsworth, S. (2006). A Conceptual Framework for Considering Learning with Multiple Representations. Learning and Instruction, 16(3), 183-198. https://doi.org/10.1016/j.learninstruc.2006.0 3.001

Anam, R. S. (2019). Analisis Representasi dan Perubahan Konsepsi Guru Serta Siswa Sekolah Dasar pada Materi Perpindahan Kalor. (Disertasi). Sekolah Pascasarjana. Universitas Pendidikan Indonesia, Bandung.

Chaifa, D. E., Diantoro, M., \& Mahanal, S. (2017). "Profil Kemampuan Representasi Peserta Didik SMP pada Materi Interaksi Makhluk Hidup dengan Lingkungan". Seminar Nasional Pendidikan Biologi dan Saintek (hlm.628634). Malang: Universitas Negeri Malang.

De Jong, T., \& Van Joolingen, W. R. (1985). Scientific Discovery Learning with Computer Simulations of Conceptual Domains. Review of Educational Research, 68(2), 179-201. doi: https://doi.org/10.3102/0034654306800217 9

Fadhilah, A. (2018). Pengaruh Pembelajaran Berbasis Multi Representasi pada Materi Sistem Pernapasan Terhadap Kemampuan Kognitif Peserta Didik di Kelas XI Lintas Minat Biologi SMA Srijaya Negara Palembang (Skripsi). Universitas Sriwijaya, Palembang.

Hand, B., Gunel, M., \& Ulu, C. (2009). Sequencing

Embedded Multimodal Representation Sin a Writing to Learn Approach to Teaching Electricity. Journal of Research in Science Teaching, 46(3), 225-247. doi: https://doi.org/10.1002/tea.20282

Hanif, N., Sopandi, W., \& Kusrijadi, A. (2013). Analisis Hasil Belajar Level Makroskopik, Submikroskopik dan Simbolik Berdasarkan Gaya Kognitif Siswa SMA Pada Materi Pokok
Sifat Koligatif Larutan. Jurnal Pengajaran MIPA, 18(1), 116-123.

Harley, J. M., Poitras, E. G., Jarrell, A., Duffy, M. C., \& Lajoie, S. P. (2016). Comparing Virtual and Locationbased Augmented Reality Mobile Learning: Emotions and Learning Outcomes. Educational Technology Research and Development, 64(3), 359-388. doi: https://doi.org/10.1007/s11423-015-9420-7

Juannita, J., \& Adhi, B. P. (2017). Pengembangan Media Pembelajaran Sistem Pencernaan Manusia Untuk Kelas 8 SMP dengan Fitur Augmented Reality Berbasis Android (Studi Kasus: SMPN 7 Depok). Jurnal Pendidikan Teknik Informatika Dan Komputer, 1(1), 7681

Kohl, B. \& Noah, D. (2006). Effects of Representation on Students Solving Physics Problems: a Fine-Grained Characterization. Physical Review Special Topics-Physics Education Research, 2(1), 10-16.

Lestari, I. D., Yuliati, L., \& Suwono, H. (2018). Kemampuan Representasi Siswa SMP dalam the 5E Learning Cycle dengan Reflective Self Assessment pada Materi Kalor. Jurnal Pendidikan: Teori, Penelitian dan Pengembangan, 3(2), 165-173.

Masruroh, R. D., Karyanto, P., \& Indrowati, M. (2014). Studi Komparasi Pemahaman Konsep Sistem Pernapasan Manusia Melalui Penerapan Pembelajaran Konstruktivisme tipe Novick Dipadu Concept Map dan Ceramah Bervariasi. Bioedukasi, 7(1), 26-31.

Nielsen, B. L., Brandt, H., \& Swensen, H. (2016). Augmented Reality in Science Education Affordances for Student Learning Abstract. Nordic Studies in Science Education, 12(2), 157-174.

doi: https://doi.org/10.5617/nordina.2399

Nurhasanah, Z., Widodo, A., \& Riandi. (2019) Augmented Reality to Facilitate Students' Biology Mastering Concepts and Digital Literacy. JPBI (Jurnal Pendidikan Biologi Indonesia), 5(3), 481-488.

Nurmalasari, R. (2016). Analisis Representasi Siswa SMP Pada Tema Kalor Dalam Perubahan Wujud Zat. (Thesis). Sekolah Pascasarjana. Universitas Pendidikan Indonesia, Bandung.

Puspaningrum, A., Mahardika, I., \& Supriadi, B. (2015). Peningkatan kemampuan multirepresentasi IPA (Fisika) dengan Model Quantum Learning disertai Metode Eksperimen pada Siswa Kelas VIII A SMP Negeri 7 Jember. Jurnal Pendidikan Fisika, 3(4), 342-348.

Sanjaya, Y., \& Rustaman, N. (2018). The Role of Visuospatial Representation to Improve 
Student's Conceptual Mastery based on Gender in Learning Human Urinary System. Journal of Science Learning, 1(3), 95-103. doi: https://doi.org/10.17509/jsl.v1i3.11790

Sari, P. (2018). Penggunaan Self-Generated Analogy Sebagai Upaya Meningkatkan Penguasaan Konsep Siswa SMA pada Materi Sistem Pernapasan. (Skripsi). Universitas Pendidikan Indonesia, Bandung.

Singhal, S., Bagga, S., Goyal, P., \& Saxena, V. (2012).Augmented Chemistry: Interactive Education System. International Journal of Computer Application, 49(15), 1-15. Sungkur, R. K., \& Panchoo, A. (2016). Augmented reality, the Future of Contextual Mobile Learning. Interactive Technology and Smart Education, 13(2), 123-146. doi: https://doi.org/10.1108/ITSE-07-2015-0017

Surasmi, W. A. (2016). "Pemanfaatan Mulitmedia untuk Mendukung Kualitas Pembelajaran". Prosiding Temu Ilmiah Nasional Guru (TING) VIII (hlm. 593-607). Surabaya: Universitas Terbuka Convention Centre

Treagust, D. F., \& Tsui, C. (2013). Introduction to Multiple Representation: Their Importance in Biology and Biological Education, in Treagust, D \& Tsui, C. (ed), Multiple Representation in Biological Education, hlm.3-18. Dordrecht, Netherlands: Springer.

Waldrip, B., Prain, V., \& Carolan, J. (2010). Using Multi-Modal Representations to Improve Learning in Junior Secondary Science. Research in Science Education, 40(1), 65-80. doi: https://doi.org/10.1007/s11165-009-

9157-6

Williamson, V. M., \& Abraham, M. R. (1995). The Effects of Computer Animation on Particulate Mental Models of College Chemistry Students. Journal of Research Science Teaching, 32(5), 521-534. doi: https://doi.org/10.1002/tea.3660320508 